\title{
EVALUATION OF INPUTS IN SURVEILLANCE SYSTEM OF SUSPECT TUBERCULOSIS CASE FINDING AT COMMUNITY HEALTH CENTERS, PALU, CENTRAL SULAWESI
}

\author{
Putri Intan Purnamasari'), Ascobat Gani'1), Yuyun Yulianti²), \\ Muh. Ryman Napirah²) \\ 1)Faculty of Public Health, Universitas Indonesia \\ 2)Faculty of Public Health, Universitas Tadulako
}

\begin{abstract}
Background: The World Health Organization goal for tuberculosis (TB) control is to detect 70\% of new, smear-positive TB cases and cure $85 \%$ of these cases. The case detection rate is the number of reported cases per 100,000 persons per year divided by the estimated incidence rate per 100,000 per year. Indonesia especially Palu still has a low detection rate of TB. This study aimed to investigate the evaluation of inputs in surveillance system of suspect TB case finding at community health centers (puskesmas), Palu, Central Sulawesi.

Subjects and Method: This was a qualitative study conducted at community health center, Palu, Central Sulawesi. Several informants were selected for this study included: head of puskesmas, TB officer, TB laboratory officer, and TB disease management program manager of Palu City Health Office. The theme of this study was evaluation of inputs in surveillance system of suspect tuberculosis case finding. The data were collected by in-depth interview, focus group discussion, and document review. The data was analyzed by descriptively.

Results: Various problems existed within the input of TB surveillance system, including man, money, material, method, and market. Some health workers showed incompetency that calls for appropriate training. Some showed low performance in TB case finding. Tasks were not distributed fairly to all health workers. The tasks were not assigned according to the competency of the health worker. Collaboration with related sectors, private sector, and community organizations was lacking.

Conclusion: The surveillance input system for TB control, particurlarly TB case finding, at community health centers was not optimal.
\end{abstract}

Keywords: input, surveilance, tuberculosis, case finding

Correspondence:

Putri Intan Purnamasari. Faculty of Public Health, Universitas Indonesia, Depok, West Java. Email: sarintano6@gmail.com. Mobile: 081918220338

\section{BACKGROUND}

According to WHO (World Health Organization), surveillance is the activity of careful and continuous monitoring of various factors that influence the incidence and spread of diseases or health problems including the collection, analysis, interprettation and dissemination of data as material for prevention and prevention. According to the Center of Disease Control (CDC), surveillance is the continuous collection, analysis and interpretation of health data needed for planning, implementing and evaluating public health efforts. From these two definitions it can be concluded that epidemiological surveillance is an activity of analysis carried out systematically or continuously on health issues in order to make effective and efficient countermeasures, through the process of collecting data, processing, interpreting and disseminating epidemiological information to health program providers (Alamsyah, 2013).

Based on the researchof Jajosky \& Groseclose (2011), it was found that the National Notifiable Diseases Surveillance System (NNDSS) reporting was on time so that it supports public health responses. Data from NNDSS is the basis for future survival. 
Because with on time reporting NNDSS can be improved detection of cases and groups of diseases. The public health surveillance system must ensure measurable timeliness for the process of specific surveillance systems and in the context of monitoring objectives. According to Indonesia's Health Profile in 2015 out of 34 provinces in Indonesia there were only 8 provinces that achieved the TB discovery target, namely North Sulawesi, Gorontalo, Southeast Sulawesi, Jambi, West Sulawesi, North Sumatra and Riau. The achievement of Indonesia's CDR (Case Detection Rate) in 2015 was $73.75 \%$, indicating that the national CDR achievement had already reached the WHOdetermined target of 70\% (Ministry of Health, 2015).

This made Indonesia as the country with the fifth rank of TB burden in the world. The cure rate and success of TB treatment in 2009 to 2014 ranged from $87-88 \%$, have fulfilled the national target $>85 \%$. The success rate of TB treatment has fulfill the target $>85 \%$, but when it was viewed in district, several districts in Central Sulawesi Province have not fulfill the target such as Palu City by $84.54 \%$, Poso Regency by 84.16\% and Balut District by $79.4 \%$. While the coverage of Central Sulawesi TB findings has not yet reached the national target of 66.3\% (Central Sulawesi Health Office, 2015).

The goal of the World Health Organization for TB control is to detect $70 \%$ of new TB cases, positive BTA and cure $85 \%$ of these cases. Case detection rate is the number of cases reported per 100,000 people per year divided by the estimated incidence rate per 100,00o per year. In 2011-2015, Palu City has not succeeded in reaching the target of the case finding standard set by the WHO at $70 \%$. The achievements in 2011 was $47.9 \%$, in 2012 it was $48.6 \%$, in 2013 it was $49.8 \%$, in 2014 it was $53.2 \%$ and in 2015 was $58.1 \%$
(Palu City Health Office, 2015). Until now, Palu City has not succeeded in achieving the target of the number of cases found in 2017.

Public Health Center (Puskesmas) is a leading health service unit close to the community and also plays a role in providing key data on public health issues for health management. One of the Puskesmas programs is P2TB which is directly under the command of the Department of Health (Nizar, 2010). To support the implementation of the P2TB program an input is needed to collect TB data to disseminate information (process) so that an output will be generated.

The Palu City Health Office overcomes 13 public health center, but 12 public health center have not reached the target of finding TB suspects while 1 health center is a new public health center so it does not have a suspect discovery target. Rate (CDR) is the output of the P2TB program which is certainly influenced by the input. So that an activity can run as expected, it is necessary to evaluate the system with the standards set in the TB surveillance activities. According to the Ministry of Health No. 1116/MENKES /SK/VIII/2003 concerning the guidelines for organizing the health surveillance system and the Ministry of Health Republic of Indonesia No. 364/MENKES/SK/V/2009 concerning guidelines for controlling tuberculosis (TB) surveillance systems can be seen from the input, process and output. An evaluation is carried out to compare the reality on the ground with existing guidelines. However, the focus of research taken is input (man, material, money, method and market). Process and output are not the main priority in this study because the input has a considerable influence on the process and output.

Therefore, this study aims to investigate the evaluation of inputs in the surveillance system for the discovery of suspected TB cases in the public health center (Puskesmas), Palu, Central Sulawesi. 


\section{SUBJECTS AND METHOD \\ 1. Study Design}

This study was a qualitative study with a case study study design, this study was conducted in 12 Palu City Health Centers. In this case, the researchers participated in the study site by looking at an overview and evaluating the Input System for Tuberculosis Discovery Surveillance (TB) in the Palu City Health Center. Researchers develop concepts and gather facts, but did not conduct the hypotheses.

Sampling technique in this study was carried out by using Purposive Sampling Technique, the sampling technique was determined directly by researchers which included Key Informants (Head of health center), Regular Informants (TB health center Officers), and additional Informants (Head of Administration and Health Center TB Laboratory Officer). Furthermore, when the data collection process was no longer found variations of information, the researcher did not need to look for new information, the process of collecting information was considered complete.

This study was conducted in January April 2017 by in-depth interviews with sub- jects/informants using the structured interview method. The interview guidelines used outline of the questions that were asked. The time of the interview with the informant was determined by the point of saturation of the informant.

\section{Study Variable}

The dependent variable in this study was TB case finding. The independent variable in this study was the evaluation of inputs in the financial system.

\section{RESULTS}

Based on education level, public health center staff generally come from a health education background of around $90.88 \%$ and the remaining $9.12 \%$ come from a non-health education background. And Based on secondary data in 12 health center, the target of finding TB suspects has not reached the national target of 70\% in 2015-2016.

Informants in this study were 33 people consisting of 13 key informants, 12 ordinary informants, and 8 additional informants. The detail of the informants can be seen in Table 1 .

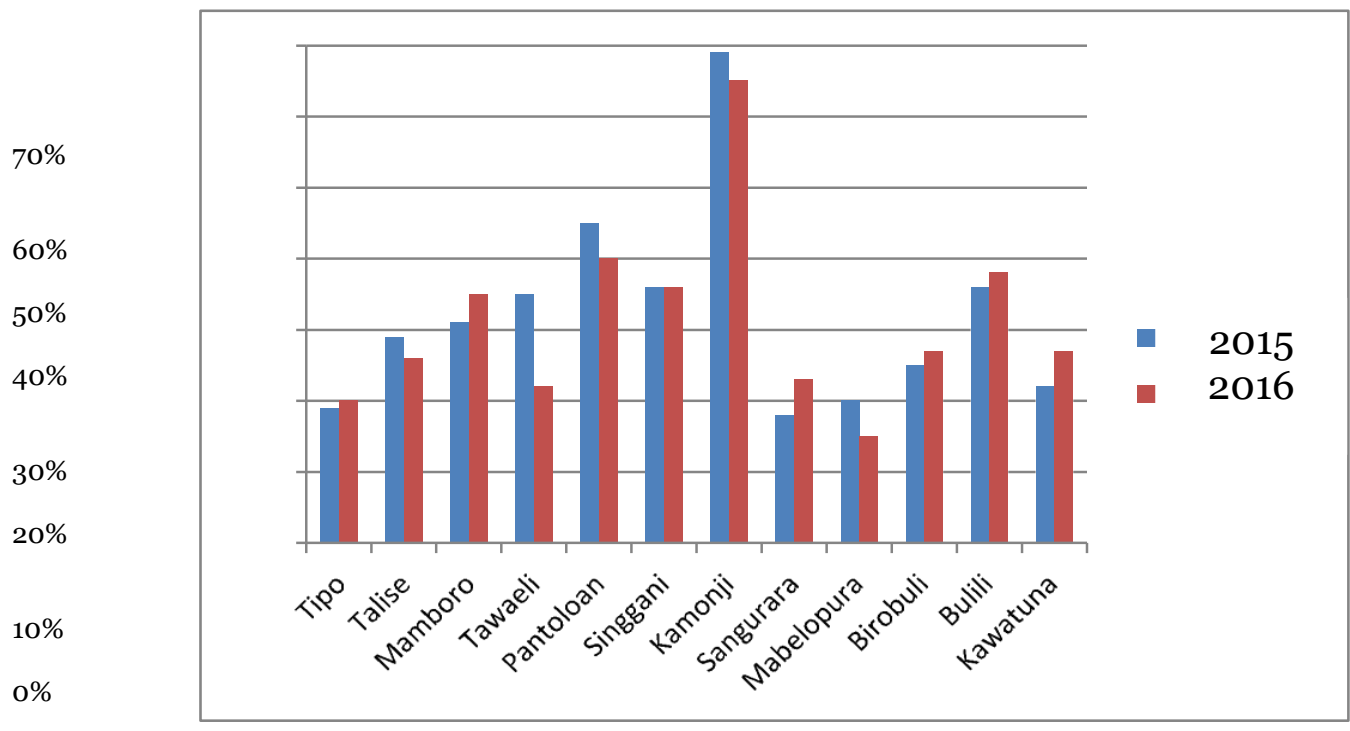

Source : Secondary Data, 2017

Figure 1. TB Suspect Discovery Results

The $6^{\text {th }}$ International Conference on Public Health 
Table 1. Informants' Characteristic

\begin{tabular}{|c|c|c|c|c|}
\hline No & $\begin{array}{l}\text { Informant's } \\
\text { Code }\end{array}$ & Education & Occupation & Type of Informant \\
\hline 1 & MI & S1 Public Health & TB Vice Supervisor & Key Informant \\
\hline 2 & NS & Doctor & Head of Puskesmas & Key Informant \\
\hline 3 & $\mathrm{RM}$ & S2 Public Health & Head of Puskesmas & Key Informant \\
\hline 4 & SV & S1 Public Health & Head of Puskesmas & Key Informant \\
\hline 5 & $\mathrm{AL}$ & S2 Public Health & Head of Puskesmas & Key Informant \\
\hline 6 & IK & Doctor & Head of Puskesmas & Key Informant \\
\hline 7 & INB & S2 Kebudayaan & Head of Puskesmas & Key Informant \\
\hline 8 & $\mathrm{RH}$ & S1 Public Health & Head of Puskesmas & Key Informant \\
\hline 9 & $\mathrm{AE}$ & Doctor & Head of Puskesmas & Key Informant \\
\hline 10 & $\mathrm{AR}$ & HS & Head of Puskesmas & Key Informant \\
\hline 11 & $\mathrm{JM}$ & S1 Public Health & Head of Puskesmas & Key Informant \\
\hline 12 & NA & Doctor & Head of Puskesmas & Key Informant \\
\hline 13 & SS & S1 Public Health & TB Officer & Key Informant \\
\hline 14 & FR & D3 Nursing & TB Officer & Regular Informant \\
\hline 15 & PR & D3 Nursing & TB Officer & Regular Informant \\
\hline 16 & $\mathrm{SN}$ & D3 Nursing & TB Officer & Regular Informant \\
\hline 17 & $\mathrm{NJ}$ & D3 Nursing & TB Officer & Regular Informant \\
\hline 18 & ML & D3 Nursing & TB Officer & Regular Informant \\
\hline 19 & $\mathrm{RN}$ & SPK & TB Officer & Regular Informant \\
\hline 20 & MR & S1 Nursing & TB Officer & Regular Informant \\
\hline 21 & YK & S1 Public Health & TB Officer & Regular Informant \\
\hline 22 & $\mathrm{ST}$ & S1 Public Health & TB Officer & Regular Informant \\
\hline 23 & SL & D3 Nursing & TB Officer & Regular Informant \\
\hline 24 & $\mathrm{SD}$ & D3 Nursing & TB Officer & Regular Informant \\
\hline 25 & LW & D3 Nursing & TB Officer & Regular Informant \\
\hline 26 & $\mathrm{AR}$ & HS & TB Lab Officer & Informant \\
\hline 27 & SJ & S1 Public Health & TB Lab Officer & Informant \\
\hline 28 & NR & S1 Public Health & Head of Administration & Informant \\
\hline 29 & $\mathrm{NF}$ & S1 Public Health & Head of Administration & Informant \\
\hline 30 & NI & S1 Public Health & Head of Administration & Informant \\
\hline 31 & $\mathrm{NN}$ & S1 Public Health & Head of Administration & Informant \\
\hline 32 & IS & HS & Head of Administration & Informant \\
\hline 33 & DF & S1 Public Health & Head of Administration & Additional Informant \\
\hline
\end{tabular}

1. Man Input Results (Resources that Support TB Suspect Surveillance Systems)

It can be concluded that for the human resource constraints at the health center, there are 6 health center whose TB officers were not only managing TB programs but were doing multiple tasks due to lack of resources available at health center. By doing multiple tasks, the officers were not optimal in doing their job. Based on observations made by researchers at the health center, there were TB patients who were not served because TB officers were not available because they were busy doing other tasks.

2. Money Input Results (Funding Supporting TB Suspect Surveillance System)

From the statement above, it can be concluded that $\mathrm{P} 2 \mathrm{~TB}$ funding in health center 
was very small. Because there was a decrease in the budget and there was no more funding from the Global Fund (GF), while the largest donor funds come from the GF.

\section{Material Input Results (Materials that Supports TB Suspect Surveillance System)}

From the statement above, it can be concluded that the availability of TB forms at the health center was available in large quantities and based on observations made by the researchers, the form was carried out in accordance with its provisions.

\section{Method Input Results (Methods that} Support TB Suspect Surveillance Systems)

Based on the conclusions above, it was found that 9 health centers only made passive service, which was waiting for patients who came then gave the counseling. Although counseling should be interspersed with suspicious selection. Whereas there were 3 health centers that conduct TB suspects although they were only done once a year. Where officers did a screening to houses and look for patients who cough for more than 2 weeks. For the guidelines, they were following the national TB control guidelines. For its availability, 3 health centers did not have these guidelines as they were missing. While the availability of microscopic examination guidelines at the health center was only owned by laboratory personnel who serve microscopic examinations.

\section{Market Input Results (Targets that} Support TB Suspect Surveillance Systems)

From the statement of the informant above, it can be concluded that all health personnels in the health center work together in implementing TB control and there was a cooperation with cross-structured programs, namely the City Health Office of Palu City and across sectors, namely districts and villages. There was no collaboration with private practices or community organizations so it was not in accordance with the guidelines.

\section{DISCUSSIONS}

1. Man (Resources that Support Tuberculosis Suspect Surveillance Systems)

Based on the research sites in 12 health centers working areas of the Palu City Health Office, there were 10 Satellite health center and two Microscopy Reference health center. According to the National TB Control Handbook, Satellite health center must have at least 1 P2TB nurse/officer trained and 1 doctor who worked together on P2TB. While the Microscopic Referral Health Center has a minimum of 1 nurse/P2TB trained staff and 1 doctor and 1 trained Laboratory Officer. Judging from the educational background of officers, there were 4 health centers that have backgrounds that were not in accordance with the guidelines. Namely 3 TB officers in 3 and 2 laboratory workers in 2 PRM according to the Republic of Indonesia Decree No. Kepmenkes. 364/MENKES/SK/2009 minimum educational background of the last TB officer is D3 Nursing and according to the Republic of Indonesia Ministry of Health on TB Laboratories Service Standards (2015) the minimum educational background of laboratory personnel is D3 Analysis.

\section{Money (Funding Supporting Tuberculosis Suspect Surveillance System)}

Based on the results of research in 12 health center, funds for P2TB are sourced from the BOK and funds from the City Health Office. In previous years, there were funds from the GF (Global Fund) but these funds did not exist anymore. This was in accordance with Ministry of Health Regulation (2014a) regarding Technical Guidelines for Health Operational Assistance, where the source of funds used in the activities to achieve pulmonary TB CDR comes from government funds, APBD/deconcentration funds/DAU District or City, 
Provincial APBD, foreign assistance and nongovernmental. Funds from BOK were only in the form of transportation for officers when there was extension activities. Therefore, based on the results of in-depth interviews with informants at the health center, it was stated that the funds obtained were not sufficient for TB surveillance activities because the allocation of funds was minimal and there were no funds for the performance of the officers. Strengthened by the results of the interview with the TB wasor that the funds, for the health center, were only to increase diagnosis and supervision. And there were no more donor funds from the Global Fund (GF), while the largest donor funds came from the Global Fund (GF).

3. Material dan Machine (Facilities and Infrastructure that Supports Tuberculosis Suspect Surveillance Systems)

Based on the results of the study in 12 health center, the TB forms were always available in large numbers of and based on observation, each form was filled in accordance with the provisions. This form supported the recording and reporting at the health center and was supported by an online reporting system called SITT (Tuberculosis Integrated Information System) so as to minimize the occurrence of missing reports, double recording and more efficient and effective so that it can get feedback from the Health Office faster. In accordance with the research of Arisandi (2011), which stated that recording form equipment such as TB 01, 02 and others were related to the quality of TB officers with a correlation coefficient of 0.522 which mean it has a fairly strong relationship.

\section{Method (Method that Supports the Tuberculosis Suspect Surveillance System)}

Based on the results of research in 12 health centers, 9 health centers used the passive case finding method. The way this method worked was to wait for patients to come and check it then the officer provided counseling to the patient or patient's family so that patients were motivated to continue treatment at the health center. According to TB officers, the case finding by visiting the patient's house was never done because this TB officer at the health center was only 1 person. However, there were 3 health centers that use 2 methods: passive case finding and active case finding. The active case finding method was only done once a year because of limited funds. In case finding, both methods should be needed, firstly passive with active promotion, then actively carried out, that is, to filter people's homes and must make a screening schedule for the screening so that it can be well directed.

And officers should be given guidelines so it can minimize errors that will be made by officers in carrying out their duties and obligations. This was in line with study done by White (2011) which stated that TB knowledge and staff attitudes that comply with national guidelines were very important for timely case finding and proper case management. National and international guidelines can form the basis for training health personnels. Therefore, it was considered appropriate for health personnels to have national guidelines.

\section{Market (Goals that Support the Tuberculosis Suspect Surveillance System)}

Based on the results of research in 12 health centers, TB workers collaborated with other health personnels in the implementation of the discovery of suspicion and collaborate with cross programs namely the Palu City Health Office and across sectors namely districts and villages. Another thing that was obtained during an interview with the TB health center staff was that one of the problems did not reach the target of finding suspicion because there had been no 
collaboration with private doctors in the neighborhood whereas many patients preferred to come to private doctors' practices and traditional healers rather than to the health center.

This was not in accordance with the TB control guidelines because there was no collaboration with the community and private practice. The collaboration of health center in the discovery of TB suspects need to be improved both with the practice of private doctors, as well as stakholders as a supporter of funds and policy makers so that the discovery of suspects in accordance with the provisions can be achieved, with full support from various parties, the implementation of TB control can run well (Mansur et al. 2015).

Based on the research on the Evaluation of Tuberculosis Suspect Surveillance System Input in the Work Area of Palu City Health Office, there were 11 health centers which have trained officers in TB control and 1 health center did not have TB trained officers, and there were $6 \mathrm{~TB}$ officers who perform dual tasks. The funds raised did not fulfill the needs of the health center and microscopic examination services. The health center used the passive case finding method in the discovery of TB suspects and was interspersed with the active case funding method and the method was done once a year. Finally, it was expected that the Head of the health center determined the minimum requirements that must be fulfilled by health personnels before becoming a program holder so that the division of tasks can be adjusted to their competencies so that the division of tasks can be evenly distributed.

\section{REFERENCES}

$\overline{\text { Alamsyah D (2013). Pilar Dasar Ilmu Ke- }}$ sehatan masyarakat (Basic Pillars of Public Health Sciences), Yogyakarta: Nuha Medika.

Arisandi P (2011). Analisis kualitas Petugas dalam pelayanan Tuberkulosisi di Pus- kesmas Kabupaten Banyuwangi Tahun 2011 (Quality Analysis of Officers in Tuberculosis services in Banyuwangi District Health Center in 2011). Tesis.

Dinkes Sulawesi Tengah (2015). Central Sulawesi Health Profile in 2015

Ditjen PP dan PL (2014). Pedoman Nasional Pengendalian Tuberkulosis (National Guidelines for Tuberculosis Control). Katalog Dalam Terbitan : Kementerian Kesehatan Nasional, 1-210.

Jajosky RA, Groseclose SL (2011). Evaluation of reporting timeliness of public health surveilance systems for infectious diseases. BMC public health, 4: 29

Kemenkes RI (2015). Standar Pelayanan Laboratorium Tuberkulosis (Tuberculosis Laboratory Service Standards).

Kementerian RI (2015). Profil Kesehatan Indonesia (Indonesian Health Profile).

Kepmenke (2009). Keputusan Menteri Kesehatan Republik Indonesia Nomor 364/Menkes/SK/V/2009 tentang Pedoman Penanggulangan Tuberkulosis (TB) (Decree of the Minister of Health of the Republic of Indonesia Number 364/Menkes/SK/V/2009 concerning Guidelines for the Prevention of Tuberculosis (TB)),

Mansur M, Khadijah S, Rusmalawaty (2015). Analisis Penatalaksanaan program Penggulangan Tuberkulosis Paru Dengan Strategi DOTS di Puskesmas Desa lalang Kecamatan Medan Sunggal (Analysis of the Management of the Pulmonary Tuberculosis Management Program with the DOTS Strategy in the Lalang Village Health Center, Medan Sunggal District).

Nizar M (2010). Pemberantasan dan Penanggulangan Tuberkulosis, Yogyakarta (Eradication and Prevention of Tuberculosis, Yogyakarta): Gosyen Publishing. 
Permenkes (2014a). Peraturan Menteri Kesehatan Nomor 1 tahun 2014 Tentang Petunjuk Teknis Bantuan Oprasional Kesehatan (Ministry of Health Regulation No. 1 of 2014 concerning Technical Guidelines for Health Operational Assistance).
White ZN (2011). Survey on the Knowledge, Attitudes and Practices on Tuberculosis (TB) Among Health Care Workers in Kingston

WHO (2012). Global Tuberkulosis Laporan (Global Tuberculosis Report). 